\title{
Ecological, biological and control studies on apple rust miteAculusschlechtendali (Nalepa) (Acari: Eriophyidae) in Egypt
}

\author{
M.M. AL-AZZAZY \\ Faculty of Agriculture, Department of Agricultural Zoology and Nematology, Al - Azhar University, Nasr City, \\ Cairo, Egypt
}

\begin{abstract}
The results showed that the population fluctuation continued at a moderate level until the mid of May and then started to increase until it reached to three peaks from the mid of June to the mid of Augustwhen the temperature degrees were at $29-27.5^{\circ} \mathrm{C}$. A s schlechtendalioccur on the underside of the leaves and their feeding produces a patchy felt-like malformation on leaf surface and yellowing of hairs. The upper surface of foliage appears speckled, dull and faded.The population of the apple rust mite A. schlechtendali was significantly highest at the interval from the end of May to the mid of August. The obtaineddata indicated thatthe total developmental time of the immature stages was $6.95 \pm 0.42$ and $7.18 \pm 0.32$ days for male and female, respectively, and the female fecundity was $54.80 \mathrm{eggs} ; 3.07 \mathrm{eggs} / 9 /$ day. Intrinsic rate of increase (rm) was found to be 0.208 individuals per female per day and the population multiplied 24.18 times in a generation time of 16.11 days under the given conditions.

The results of control pest experiments indicated that the Abamectin was superior in reducing the apple rustmiteA.schlechtendali( $96 \%$ reduction) compared to Chlorfenapyr and Sulphur which had approximately equal reductions (88and $84 \%$ reductions, respectively).

The study ended with the conclusion that. The apple rust miteAschlechtendaliis considered to be disastrous as its intrinsic rate of increase (rm) is high and the best control of this species at this interval was attained with Abamectin.
\end{abstract}

Keywords: Ecology, biology, control, apple rust mite.

\section{Introduction}

Apple (Maluspumila ., L) is commercially the most important temperate fruit and is fourth among the most widely produced fruits in the world after banana, orange and grape. In Egypt, apple trees are liable to be infested with several major injurious mitesAculusschlechtendali

(Nalepa),Tetranychusurticae Koch, Panonychusulmi (Koch) which cause severe damage and reduced plant growth and production (Abdel-Wahed,2003). The most obvious damage caused by this mite in most apple-growing areas is a browning or rusting of the under sides of leaves during the summer. The mites emerge and invade the opening fruit buds to feed. Breeding of the mites continues throughout the spring and summer, forming several overlapping generations of primary forms. New deutogynes appear in increasing numbers from late June or early July onwards. The population growth is rapid; egg to adult can occur in 1-2 weeks with warm summer temperatures (Alford, 1984). The present investigations were carried out to evaluate the population fluctuation of the apple rust mite, $A$. schlechtendaliand its developmental time stages, life table and reproductive parameters as well as control of this phytophagous mite species on appletrees by using three acaricides to evaluate their effect in reducing the population densities of this a serious mite.

\section{Material and methods}

\section{Ecological studies}

The experiments for estimating the population fluctuations of the apple rust mite,A.schlechtendali, were carried out in an abandoned apple orchard(MalusdomesticaBorb.), ten-years old,for one year (April 2013to March 2014). Half an acre from Anna cultivar of similar size, vigor and shape were selected, IntheNubaria region, Egypt. In order to study the population of eriophyid mite species, leaf samples were collected weekly, starting on 7 Apriluntil endof March. Twenty apple leaves were taken randomly from apple trees and placed directly into plastic bags and transported to the laboratory. All mite stages (eggs, immature and adults) were counted using stereoscopic binocular microscope and the average numbers of mite were tabulated.

To determine the number of annual generations of $A$. schlechtendali under environmental conditions, the percentage of immature stages was estimated weekly. Period at which the highest percentage of the immature stages occurred presented a generation. Daily rate of temperature and relative humidity was taken from the central Meteorological Department, Ministry of Scientific Research, for the climatic factor prevailing in the locality and corresponding to sampling periods. 


\section{Biological studies}

Many unsuccessful trials were performed in rearing eriophyidapple mites on lower or upper surfaces of different succulent young, inter medium or old leaves. These trails were mostly based on known methods used for several other species of eriophyoidmites (Abou-Awad 1979, 1981; Easterbrook 1979; Abou-Awadet al. 2000).In addition petri-dishes or plastic cages were prepared and many chemical attractants and repellants were used for rearing purposes. However, all these trails were unsatisfactory and only the method described below was adequate.

A medium consisted of: Agar $8.0 \mathrm{~g}$, Murashige and Skoog $1.1 \mathrm{~g}$, Rosebengal 1.0, indole acetic acid1.0 ml, solved in distilled water $1000 \mathrm{ml}$.Agar was transferred to vial and was melted using a boiling water bath, then a vial was removed. Murashige and skoag was agitated in the melted agar till dissolved. The obtained mixture was then sterilized by adding rose bengal which was dissolved by agitation. Thereafter, indol acetic acid was added to the dissolved mixture. Soft lateral apple branches were washed and divided into parts of $12-15 \mathrm{~cm}$ length. All attached leaves were removed, except one leaf was left for each part of the divided branches to rear the eriophyid species. Cutting were dipped, for two second, into indol acetic acid to encourage developing roots, before inserting into tubes containing the above-cited prepared medium.

Fifty newly mated females for the apple rust mite A.schlechtendali were obtained from heavily infested apple leaves, and placed singly on the leaves of cuttings by mean of a human eyebrow, fastened to a handle. Each female was allowed to deposit one to two eggs, then it was removed. According to ecological study, treated cuttings were placed in the incubator at $\left(30{ }^{\circ} \mathrm{C}\right.$ and $70 \%$ r. H. $)$. Mite development was observed twice daily. After the last moult of either sex and to insure insemination by spermatophores produced by males, each newly emerged female was transferred, for $24 \mathrm{~h}$, toa leaf previously inhabited by an adult male, and then females and males were transferred back to their original leaves. (Keifer's 1954) three-step recipes for fixation and embedding were used.

\section{Chemical control}

The apple trees (cultivar Anna) were planted. 1300 trees per hectare were planted.An area of the same abandoned apple orchard with a history of eriophyid mite infestationswas selected to study the effect of chemical control on this phytophagous mite speciesby using three chemical compounds: Abamectin $1.8 \%$ (EC at the rate of $40 \mathrm{ml} / 100 \mathrm{~L}$ water, $240 \mathrm{ml} /$ Feed.), Sulphur (Micronized sulphur $99.8 \%$ at the rate of $250 \mathrm{~g} / 100 \mathrm{~L}$ water, $1.5 \mathrm{~kg} /$ Feed.) and challenger (Chlorfenapyrat the rate of $40 \mathrm{ml} / 100$ $\mathrm{L}$ water, $240 \mathrm{ml} / \mathrm{Feed})$. Treatments were carried out when eriophyid mite population started to increase.
Each treatment was replicated four times (a replicate $25 \mathrm{~m}$ ). The experimental design was complete randomized block. Sixty leaves of each treatment were randomlycollected and placed directly into plastic bags separately and transported to the laboratory. All mite stages were counted using stereomicroscope, to determine the initialdistribution and density of the mites as pre-spray counts. Observation was made, three days and four weeks after the application, to evaluate the reduction percentage of the pest populations on the wheat plants after treated by the three chemical compounds. Spray was applied with a conventional hand spray gun.

\section{Data recording and analysis}

The life table parameters of the apple rust mite A.schlechtendaliwere calculated with two-sex software, developed by (Chi 1997). The programme calculates the intrinsic rate of increase $(\mathrm{rm})$, the finite rate of increase $(\lambda)$, the net reproductive rate (Ro) and the mean generation time $(\mathrm{T})$. The life table was constructed according to (Birch 1948).

The reduction percentages of the average population number of phytophagousmitesspecies were calculated according to the equation of (Henderson and Tilton 1955).

Reduction

$$
=1-\frac{\text { Treatement after } \times \text { control before }}{\text { treatment before } \times \text { control after }} \times 100
$$

One-way analysis of variance (ANOVA) and mean comparison using Fisher's least significantdifference were conducted for development time, the number of eggs depositedand number of prey consumed, using super ANOVA programme (Gagnonet al. 1989). Significance level was

$\mathrm{P} \leq 0.05$.

\section{Results and discussions}

\section{Ecological studies}

The population fluctuations of the apple rust mite A.schlechtendali were studied on the apple trees (cv.Anna) for one year and weather records are presented in Fig.(1) in 2013/2014, A.schlechtendali appeared during the first week of April 2013 when new Anna apple leaves protruded from the buds. Average temperature and R.H. during that time were $23{ }^{\circ} \mathrm{C}$, and $75 \%$, respectively, as shown in Fig.(2). It is of interest to note that during development,A.schlechtendali displayed deuterogyny which is the occurrence of two types of females, primary and secondary (Herbert, 1974, Easterbrook, 1979 and Alford, 1984). In early April at the beginning of the growing season, the deutogynes started egg-laying. The new progeny or protogynes were commonly found on the leaves from early April until the mid of November. Deutogynes 
of A. schlechtendali hibernated mainly in small permanently dormant buds and under loose bark on spurs and around buds on 1-yr shoots, and moved into fruit buds between the bud burst and pink but stages and into vegetative buds as the buds began to swell Fig.(2)Shows the relation between time (weeks) and each of population of A.schlechtendali, temperature $\left({ }^{\circ} \mathrm{C}\right)$ and R.H. $(\%)$.

The populationfluctuation continued at a moderate level until the end of May, and then started to increase until reaching to the first peak on mid of June (199 individuals/leaf at average temperatures 29 ${ }^{\circ} \mathrm{C}$ and $76 \%$ R.H.), after that, the mite population decreased for two weeks followed by a sharp increase to the second peak on mid of July (219 individuals/leaf at average temperatures $26{ }^{\circ} \mathrm{C}$ and $83 \%$ R.H.). And then, their population decreased for three weeks followed by a sharp increase until reaching to the third and largest peak on mid of August (245 individuals/leaf at average temperatures $27{ }^{\circ} \mathrm{C}$ and $82 \%$ R.H.), after that, gradually decreased until reaching zero individual mites per leaf from December until March. About 11 generations of $A$. schlechtendali were recorded on apple leaves during the study period. The longest generation for $A$. schlechtendali was that, which passes throughout fall months and lasted for about five weeks, while the shortest generation occurredin summerand lasted for about two weeks. This confirms again that the changeable environmental factors had a great effect on the apple rust mite and the severe damage occurred in summer.

\section{Biological studies}

Life cycle stages and behaviour observations of the apple rust mite Aculusschlechtendali: the mite was able to develop successfully from egg to adult through the entire life history at $30{ }^{\circ} \mathrm{C}$ and $70 \%$ R.H. The incubation period of the male was shorter than that of the female $(2.69 \pm 0.18$ and $2.80 \pm 0.12$ days respectively, Table (1). The first instar nymph resembles the adult in many respects, but is smaller, without external genitalia, which may be slightly different in nature and in microtuberculation. The first nymph istranslucent, $69-85 \mu \mathrm{m}$ long, relatively active and only vagrants around the scales. It passes through nymphochrysalis before moulting into the second instar nymph. Protonymphal development rate was $2.12 \pm 0.16$ for male and $2.11 \pm 0.11$ days for female Table (1). The second instar nymph is very much similar to the first, creamy-white in colour, 95-105 $\mu \mathrm{m}$ long, more active and vagranting on the entire lower surface of the leaf. The second nymph passes through an imagochrysalis before moulting and giving rise to the adult. It was observed that during the quiescent stages, the individual stretched its legs directly forward parallel to each other, and the mite fastened itself slightly to the plant surface at the same site as the mite feeds and lay eggs or any other sheltered site on the under surface of the leaf.
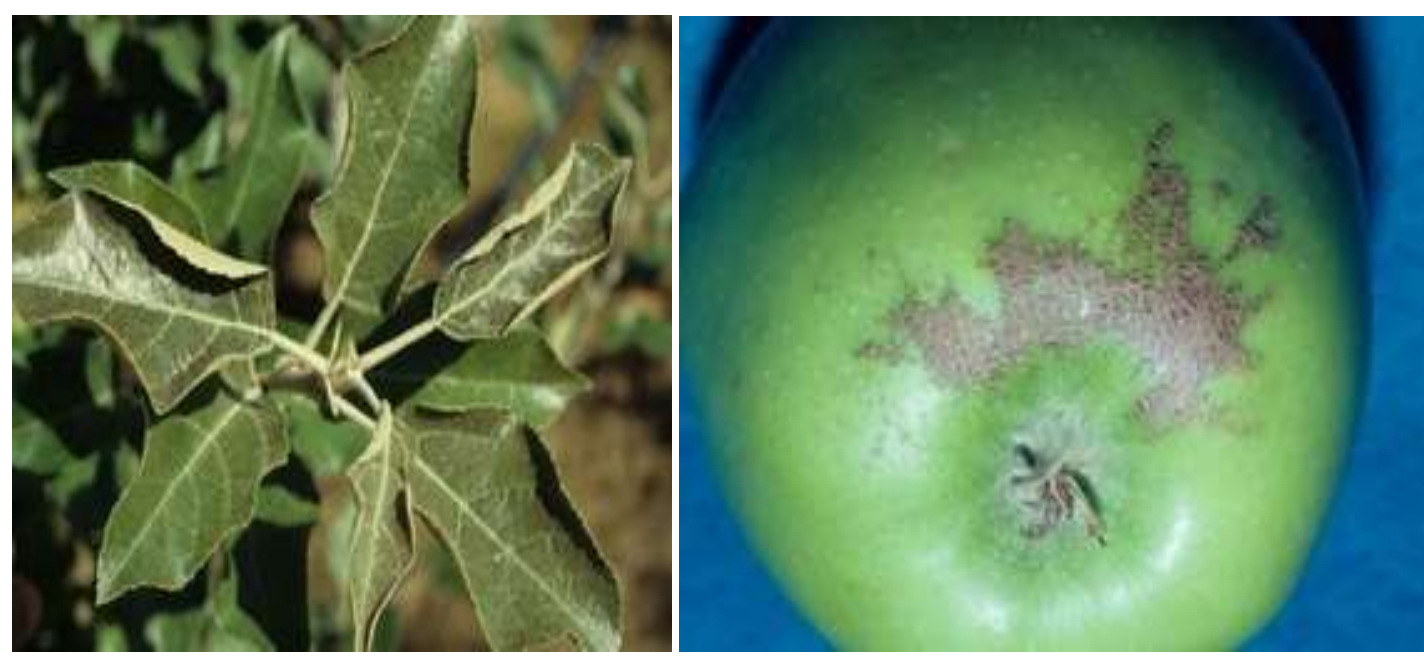

Figure 1.Leaves and fruits infested by A. schlechtendali 

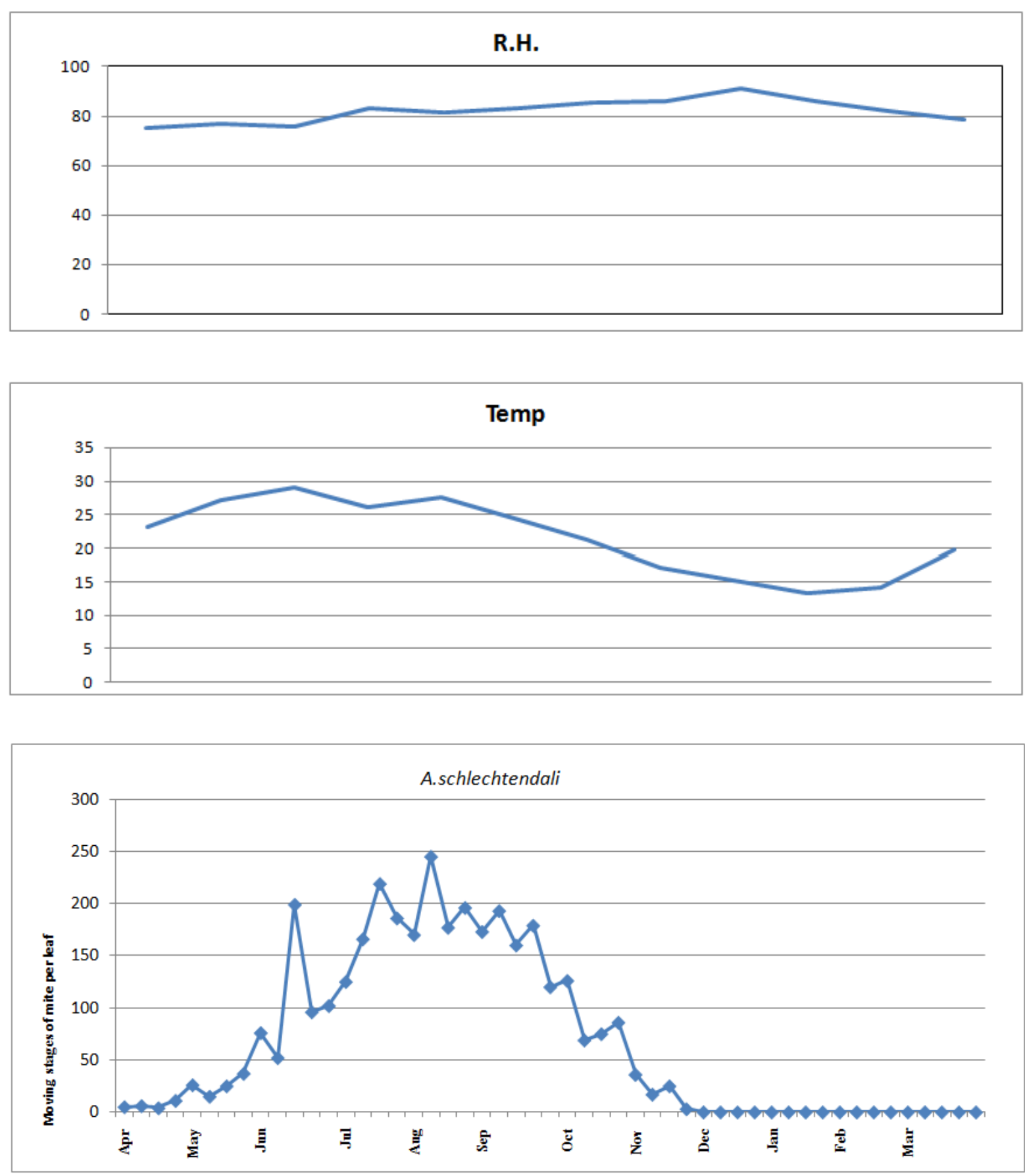

Figure 2. The relation between time (months) and each of the population of A. schlechtendali on apple leaves temperature $\left({ }^{\circ} \mathrm{C}\right)$ and R.H. $(\%)$.

Table 1. Average duration in day's immature stages of the apple rust mite Aculusschlechtendali(Nalepa) at 30 ${ }^{\circ} \mathrm{C}$ and $70 \%$ R.H.

\begin{tabular}{ccccccc}
\hline Sex & & \multicolumn{2}{c}{ First instar nymph } & \multicolumn{2}{c}{ Second instar nymph } & Life cycle \\
\cline { 3 - 6 } \cline { 3 - 5 } & Egg & M & N & M & I & Mean \pm SD \\
& Mean \pm SD & Mean \pm SD & Mean \pm SD & Mean \pm SD & Mean \pm SD & \\
\hline Female & $2.80 \pm 0.12$ & $2.11 \pm 0.11$ & $0.24 \pm 0.06$ & $1.79 \pm 0.16$ & $0.24 \pm 0.04$ & $7.18 \pm 0.32$ \\
Male & $2.69 \pm 0.18$ & $2.12 \pm 0.16$ & $0.24 \pm 0.04$ & $1.66 \pm 0.19$ & $0.24 \pm 0.08$ & $6.95 \pm 0.42$ \\
\hline
\end{tabular}

Notes: M: Moving stage N: Nymphochrysalis I: Imagochrysalis.

The moulting form has a pearly luster and is motionless. In the moulting process, a transverse rupture occurred at the anterior region behind of the cephalothoracic shield, hence legs and the cephalothorax were the first parts to the plant surface; the anterior parts were then elevated and 
mite moved to get rid of the exuvium. Deutonymphal development rate was $1.66 \pm 0.19$ for male and 1.79 \pm 0.16 days for female.After theactive protonymphal or deutonymphal stages, the mites undergo a nymphochrysalis period (quiescent) which lasted approximately $1 / 10$ of the duration of the active stages.

The female life cycle lasted 7.18 days, while the male developed faster 6.95 days at $30{ }^{\circ} \mathrm{C}$ and $70 \%$ RH Table (1). Insemination took place soon after female emergence from the last quiescent stage. It was noted that the mating process was essential for the maximum reproduction of the females, as unmated females deposited lower numbers of eggs compared to mated ones.

Unfertilized females were found to produce only male off springs, while both males and females were produced by fertilized females. The findings of these studies in general agree with (Burdittet al. 1963), (Easterbrook 1979), (Abou-Awadet al. 2000) and (Al-Azzazy, 2005, 2010 and 2013) on other eriophyid mite species in many aspects but differ markedly in others. The pre-ovipositional time averaged $2.10 \pm 0.14$ days. Female deposited an average of 54.80 eggs, during an ovipositional period. The maximum number of eggs laid by one female was 68 eggs and the minimum was 41 . The duration of the ovipositional period ranged from 15 to 20 days, with an average of $17.8 \pm 1.14$ days. The post-ovipositional time averaged $3.80 \pm 0.42$ days (Table 2).

\section{Life table and reproductive parameters}

Data in Table (3) clearly shows that thelife table parameters for Aculus schlechtendali demonstrated that the intrinsic rate of increase was 0.208 individuals/ + /day; the population multiplied 24.18 times in a generation time of 16.11 days at 30 ${ }^{\circ} \mathrm{C}$ and $70 \%$ R.H. therefore, it could be concluded that the highest temperature and relative humidity accelerated the rate of development and induced more reproduction of the apple rust mite Aculus schlechtendali. Thus, warm and humid climatic conditions are the most important factors favoring a population increase. Based on the above results, Aculus schlechtendaliis considered to be disastrous mite on apple orchards, particularly in summer months.

Table 2. Duration time of the adult female and male apple rust mite Aculus schlechtendali(Nalepa)at $30{ }^{\circ} \mathrm{C}$ and $70 \%$ R.H.

\begin{tabular}{ccccccc}
\hline Sex & $\begin{array}{c}\text { Pre- } \\
\text { oviposition } \\
\text { Mean } \pm \text { SD }\end{array}$ & $\begin{array}{c}\text { Generation } \\
\text { Mean } \pm \text { SD }\end{array}$ & $\begin{array}{c}\text { Oviposition } \\
\text { Mean } \pm \text { SD }\end{array}$ & $\begin{array}{c}\text { Post- } \\
\text { oviposition } \\
\text { Mean } \pm \text { SD }\end{array}$ & $\begin{array}{c}\text { Longevity } \\
\text { Mean } \pm \text { SD }\end{array}$ & $\begin{array}{c}\text { Life span } \\
\text { Mean } \pm \text { SD }\end{array}$ \\
\hline Female & $2.1 \pm 0.14$ & $9.28 \pm 0.38$ & $17.8 \pm 1.14$ & $3.8 \pm 0.42$ & $22.70 \pm 1.41$ & $29.88 \pm 2.19$ \\
Male & - & - & - & - & $19.22 \pm 1.47$ & $26.17 \pm 1.84$ \\
\hline
\end{tabular}

Table 3. Life table parameters of the apple rust mite Aculus schlechtendali(Nalepa) at $30{ }^{\circ} \mathrm{C}$ and $70 \%$ R.H.

\begin{tabular}{ll}
\hline Parameters & Aculus schlechtendali \\
\hline Mean total fecundity (Eggs/Q) & 54.80 \\
Net reproductive rate (Ro) & 24.18 \\
Mean generation time $(\mathrm{T})$ & 16.11 \\
Intrinsic rate of increase $(\mathrm{rm})$ & 0.208 \\
Finite rate of increase $(\lambda)$ & 1.28 \\
$50 \%$ mortality (in days) & 27 \\
Sex ratio (Female/total) & $20 / 30$ \\
Sex ratio (female: male) & $2: 1$ \\
\hline
\end{tabular}

\section{Controlling the apple rust mite}

Table (4).shows that the reduction percentages of the apple rust mite populations were significantly different among the three treatments $(\mathrm{p}<0.01)$. Results indicate that the application of Abamectin resulted in a promising control against the apple rust mite A. schlechtendalias it caused a reduction of $96 \%$ in the population during the 26 days period following the application. Chlorfenapyr and Sulphurhad remarkable less reduction compared to Abamectin and their reductions of both were approaching each other (88 and 84\%, respectively). Similar effects of Abamectin against the apple rust mite $A$. schlechtendali on apple trees (LaimutisRaudoniset al 2007) and eriophyid mite species were found on citrus in Florida (Childers, 1986) and on olive trees in Egypt (Al-Azzazy 2002, 2005).In conclusion, the studies indicate that the population of the. Apple mite A. schlechtendali was significantly highest at the interval from the mid of April to the mid of July .From the life history data, a life table was constructed and the intrinsic rate of increase (rm) was 0.208 individuals//O //day. The population multiplied 24.18 times in a generation time of 16.11days. These statistics form one of the important components in an appraisal of the ability of increasing this pest mite. Also, the Abamectin is efficient in suppressing this mite species. 
Table 4. The population average numbers of the apple rust mite Aculusschlechtendali/leaf and their corresponding reduction percentage by the three acaricides on the apple trees.

\begin{tabular}{lllll}
\hline & \multicolumn{4}{c}{ Number of mites/leaf } \\
\hline Acaricides & Con. \% & Pre-spray count & $\begin{array}{c}\text { Average post-spray } \\
\text { count }^{\mathrm{a}}\end{array}$ & Reduction\% \\
\hline Abamectin & 0.04 & 289 & 12 & 96 \\
Chlorfenapyr & 0.04 & 298 & 36 & 88 \\
Sulphur & 0.30 & 305 & 49 & 84 \\
Control & - & 277 & 281 & - \\
\hline
\end{tabular}

Counts were made from 1 and 3 as well as 26 days after the application.Means followed by a different subscript letter in column are significantly different $(\mathrm{P} \leq 0.05)$.

\section{References}

Abd El-Wahed, N.A. (2003)

Studies on some mites associated with certain fruit trees. Ph.D. Thesis, Fac. Agric., Al-Azhar Univ. 179 pp.

Abou-Awad, B. A. (1979).

The tomato russet mite, Aculopslycopersici(Massee) (Acari: Eriophyidae) in Egypt.

Anz.Schädlingsk.Pflanzensch.Umweltsch.25, 153$156,1979$.

Abou-Awad, B. A. (1981).

Bionomies of the mango rust mite Metaculusmangiferae(Altiah) with description of immature stages (Eriophyoidea: Eriophyidae).

Acarologia22, 151-155.

Abou-Awad BA, El-Sawaf BM, Reda AS, AbdelKhalek AA. (2000).

Environmental managementand biological aspects of two eriophyid fig mites in Egypt: Aceriaficus and Rhynchophytoptusficifoliae.

Acarologia. 40:419-442.

Al-Azzazy, M. M. (2005).

Integrated management of mites infesting mango trees.

Ph.D. Thesis, Fac. Agric., Al-Azhar Univ.322 pp.

Al-Azzazy, M.M. (2010).

Biological aspects of pear bud mite Eriophyespyri (Pagenstecher) (Acari: Eriophyidae) under different temperatures in Egypt.

J Plant Protec Pathogen. 1(9):673-679.

Al-Azzazy, M.M.; Abdallah, A.A. and El-Kawas , H.M.G.(2013).

Studies on the wheat curl mite, AceriatulipaeKeifer (Eriophyidae) in Egypt

Arch.ofPhytopath. and Plant Protec., Vol 46, 11501158.

Alford, D.V., (1984).

A Colour Atlas of Fruit Pests, their Recognition, Biology and Control.

Birch LC. 1948. The intrinsic rate of natural increase of an insect population. J Animal Ecol.17:15-26.

Birch LC. (1948).

The intrinsic rate of natural increase of an insect population.

J Animal Ecol.17:15-26.

Burditt, A. K.; Jr, D. K.; Reed, C. R. (1963).
Crittenden: Observations on the mites Phyllocoptrutaoleivora

(Ashmed) and AculuspelekassiKeifer under laboratory conditions.

Florida Entomol. 46, 1-5.

Chi H. (1997).

Computer program for the age-stage, two-sex life table analysis.

Taichung: National Chung HsingUnivesity.

Childers CC. (1986).

Methods for the routine screening of acaricides against the citrus rust mite Phyllocoptrutaoleivora (Ashmed) Acari: Eriophyidae).

Brit Crop Protect Conf Pests and Diseases. 3:C-17.

Easterbrook, M.A., (1979).

The life-history of the eriophyid mite Aculusschlechtendali on apple in South-East England. Ann. Applied Biol., 91: 287-296.

Gagnon J, Roth JM, Carroll M, Haycock KA, Plamondon J, Feldman DS, Simpsoon J. (1989).

Super ANOVA accessible general linear modelling. Berkeley (CA): Abacus Concepts.

Henderson CF, Tilton EW. (1955).

Test with acaricides against the brown wheat mite. J Econ. Entomol. 48:157-161.

Herbert, J.H. (1974).

Notes on the biology of the apple rust mite, Aculusschlechtendali (Prostigmata: Eriophyidae), and its density on several cultivars of apple in NOVA NOVA SCOTIA1Canadian Entomologist / Volume 106 / Issue 10 / October 1974, pp 1035-1038.

Keifer, H. H.: Eriophyid studies XX11: Bull., Calif. Dept.

Agric. 43, 121-131, 1954

Laimutis RAUDONIS, Alma VALIUŠKAITÉ, Elena SURVILIENE் (2007)

Toxicity of Abamectin to rust mite, Aculusschlechtendali (Acari: Eriophyidae) in apple tree orchard

SODININKYSTE் IR DARŽININKYSTÉ 2007. 26 (2)

http://vddb.library.1t/obj/LT-eLABa-

0001:J.04 2007 ISSN_0236

4212.V_26.N_2.PG_10-17. 


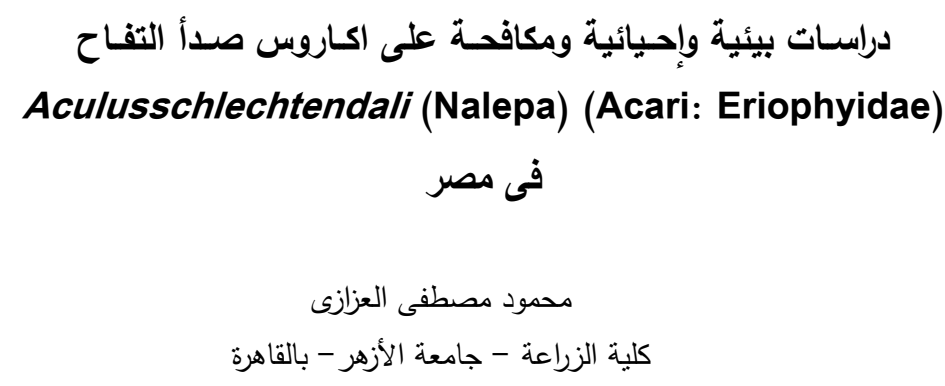

تم إجراء الدراسة على أكاروس صدأ التفاح A. schlechtendali اتضح ان تعداد الأكاروس كان منوسطاً فى منتصف شهر مايو ثم بدأ التعداد فى الزيادة ووصل الى الذروة ثلاث مرات فى الفترة من منتصف يونيو حتى منتصف أغسطسحيث كانت درجة

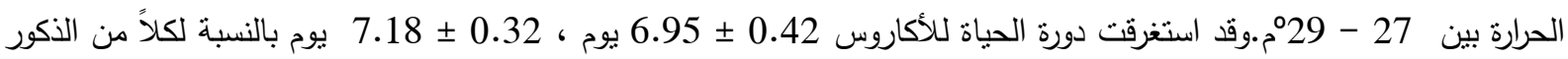
والأناث على النوالى.وتم استخدام ثلاث أنواع من المبيدات الكيميائية ضد هذا الأكاروس وكان اكفأ هذه المبيدات أبامكتين بنسبة خفض 96\% يليه كلاً من كلوروفينابايربنسبة خفض 88\% ثم سلفار بنسبة خفض التض 